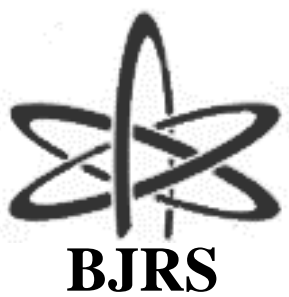

\author{
BRAZILIAN JOURNAL \\ $\mathrm{OF}$ \\ RADIATION SCIENCES \\ 07-02A (2019) 01-12
}

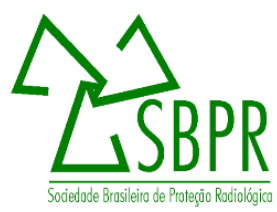

\title{
PRE-TREATMENT OF BITUMINIZED NPP WASTES FOR DISPOSAL IN NEAR-SURFACE REPOSITORY
}

\author{
Vanessa Mota Vieira ${ }^{a}$, Clédola Cássia Oliveira de Tello ${ }^{a}$ \\ ${ }^{a}$ Centro de Desenvolvimento da Tecnologia Nuclear (CDTN / CNEN), Av. Presidente Antônio Carlos, 6.627 \\ 31270-901 - Campus da UFMG, Pampulha, Belo Horizonte, MG. vanessamotavieira@gmail.com;
}

\begin{abstract}
The implementation of the national repository is an important technical requirement, and a legal requirement for the entry into operation of the nuclear power plant Angra 3. The Brazilian repository is being planned to be a near-surface one. In Brazil the low and intermediate level radioactive wastes are immobilized using cement and bitumen for Angra 1 and Angra 2 NPP, respectively. The main problems due to the disposal of bituminized wastes in repositories are sweling of the waste products and their degradation in the long term. To accommodate the swelling of the bituminized wastes, the drums are filled up to $70-90 \%$ of their volume, which reduces the structural the repository stability and the disposal availability. Countries, which use bitumen in the solidification of NPP's radioactive waste and have near-surface repositories, need to immobilize this bituminized waste within other drums containing cement pastes or mortars to disposal them. This study aims to find solutions for the storage in surface repository of bituminized radioactive waste products, making them compatible with the acceptance criteria of cemented waste products. It was also performed a modeling with the results obtained in the leaching test using the ALT program and defined the transport model of the cesium leachate element and it was verified that in the early times the leaching was governed by the diffusion model and later by the partition model. The results obtained in this study can be used in the evaluation of performance of repositories.
\end{abstract}

Keywords: Radioactive wastes, bitumen, cement pastes, mortars, encapsulation.

\section{INTRODUCTION}

In Brazil, there are currently two nuclear power plants with PWR type in operation, located in Itaorna, Rio de Janeiro: Angra 1, Angra 2 and Angra 3 under construction. Angra 1 has the capacity 
to generate $640 \mathrm{MW}$ and Angra 2, $1350 \mathrm{MW}$. Angra 3 is expected to generate $1405 \mathrm{MW}$ (Figure 1) [1].

In the Brazilian Nuclear Program, it was predicted the construction of, at least, four nuclear power plants in the Northeastern and the Southeastern regions of Brazil, until 2030, to meet the increased use of nuclear power to generate electricity $[1,2]$. With this growth and the increased use of radionuclides in different areas, the issue of radioactive waste deserves governmental actions that are being taken to resolve issues related to their storage [3].

Figure 1: Brazilian Nuclear Power Plants: left below - Angra 1 and 2; right above: Angra 3

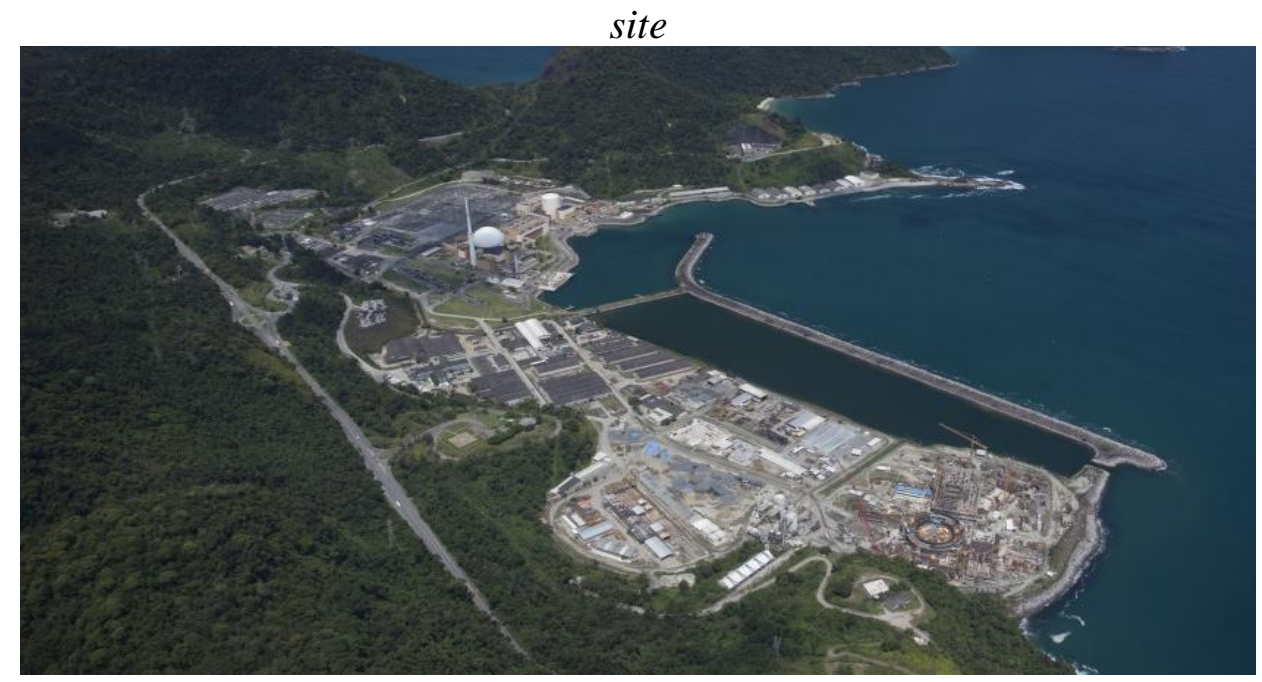

Source: eletronuclear, 2017

Brazilian Federal Law 10308 regulates the final destination of the radioactive waste produced in the country, including site selection, construction, licensing, operation, supervision, costs, damages, liability and warranties related to the deposit of radioactive waste. The responsibility of CNEN for the final destination of the waste is established in Article 2. According to this regulation, it is not allowed to receive radioactive waste in liquid or gaseous forms in final repositories [4].

Therefore the solidification of the waste is required in order to meet three basic criteria to ensure safe handling of radioactive waste in repositories, which are mechanical resistance, permeability and stability. The matrices used can be cement polymers, glass and bitumen [5]. 
The immobilization and solidification of radioactive waste of low and intermediate radiation levels (evaporator concentrates and spent ionexchange resins) from Angra 1 and Angra 2 are carried out in cement and bitumen respectively [1].

There are also major problems due to the presence of bituminization products in repositories, which are swelling of the product and waste product long term degradation caused by fissures, softening by temperature variations, creeping because of its viscoplastic material, attacked by micro-organisms and, under certain conditions, fire hazard. To accommodate swelling, the drum must be filled in the range of $70-90 \%$ of its volume, which can decrease the structural stability of the repository and increase the necessary disposal of this area $[8,10]$.

The "RBMN Project" was launched in November 2008 and aimed to implement the Brazilian Repository, from its conception to its construction. The concept adopted was a near-surface repository designed constructed according to the inventory of radioactive wastes, including those from the operation of nuclear facilities, from the facilities of the nuclear fuel cycle, and from the use of radionuclides in medicine, industry and research activities in Brazil. The implementation of the national repository was an important technical requirement and currently a legal requirement for the entry into operation of the plant Angra 3 [2].

Most of the waste to be disposed in the repository will be from nuclear power plants. The acceptance requirements for disposal of these wastes are directly linked to the safety of the entire installation. Therefore, a solution for the storage of bituminized waste must be obtained to ensure the performance expected by the safety analysis.

This study aims at looking for pretreatment solutions to dispose the bituminized waste products in the repository, making them compatible with the facility's waste acceptance criteria of cemented waste products.

\section{NPP WASTE BITUMINIZATION IN THE WORLD}

The encapsulation of radioactive waste in bitumen is also used in Romania, Slovakia and the Czech Republic and in a nuclear power plant in Switzerland. This process was first used in other countries such as France, Belgium and Spain, and it was planned to be used in a new nuclear power 
plant in Argentina. However, these countries abandoned and replaced it by other processes, after the evaluation of the total cycle of waste from its generation to its disposal $[7,8]$.

In general, most of the waste generated has low and intermediate levels of radiation. The most common method of final disposition (disposal) of this type of waste is its confinement in near surface repositories (Figure 2). The proposal of the Nuclear Energy Agency (OECD / NEA) is to establish benchmarks and provide generic guidance on the methodology that can be used by national authorities to establish acceptance of criteria for the specific location of the repository. Here are described three types of criteria:

- Limits on the concentration of radionuclides in the waste;

- Limits on the total activity of radionuclides to be disposed in a given installation;

-Standard performance for packaged and packaging waste [9].

Authors must describe materials, data, and associated protocols in order to allow other researchers to replicate the study.

Figure 2: Near surface repository

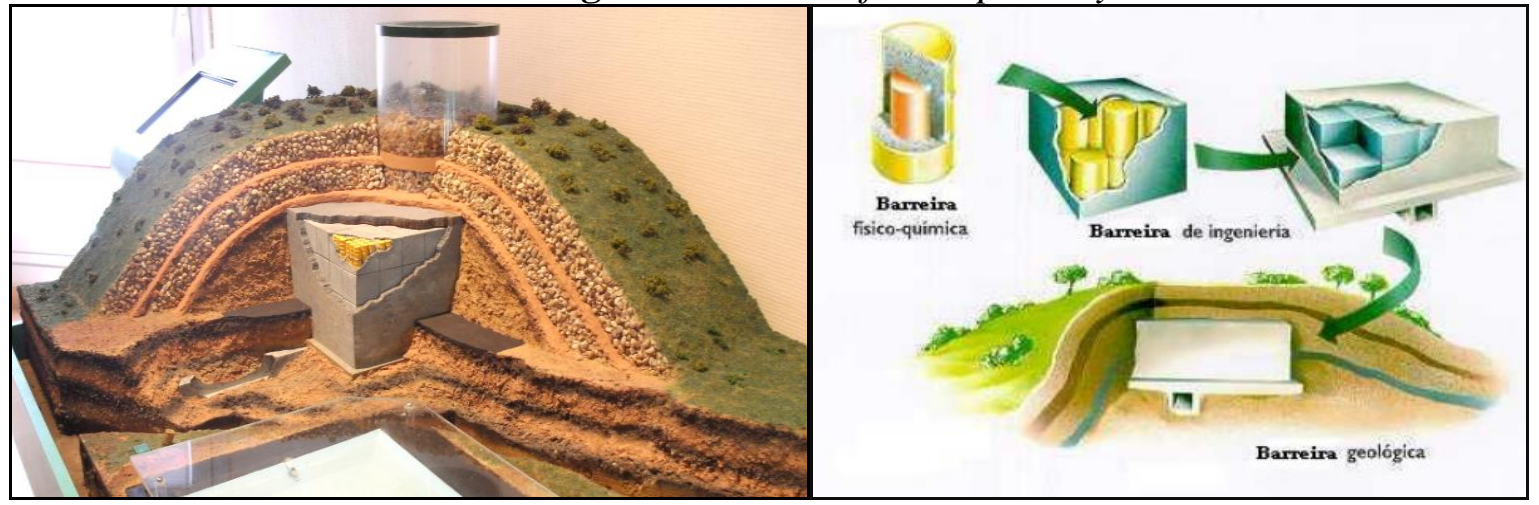

Source: Tello, 2008.

Experiences from bituminized waste disposal on surface repository were reported in countries like Romania, where ion exchange resins are encapsulated in bitumen in 60 liter drums, which are then packed in $200 \mathrm{~L}$ drums with intermediate concrete shielding. In Slovakia, radioactive wastes are incorporated into bitumen and this mixture is stored in $200 \mathrm{~L}$ drums coated with zinc (galvanization), deposited in containers and transported to the Mochovce surface repository. In the Czech Republic, 100L waste drums are encapsulated by high strength concrete in 200L drums, plates and 
galvanized corrosion-resistant paint, and then sent to the Dukovany repository. Other countries such as France and Belgium have opted for bituminized waste disposal on deep geological repositories, minimizing the risks associated with these wastes. Even for bituminized waste disposal on deep geological repositories is carried out preliminary encapsulation process [9, 10].

\section{MATERIALS AND METHODS}

As options for disposal of the bitumenized waste in the surface repository, it was encapsulated in pastes or mortars, generating a new product that meets the acceptance criteria of CNEN NN 6.09 and ensures safety and performance in the operating phases and closing the repository. For this, the bitumen (VIT 70) and the pastes and mortars were initially studied. Then the final product formed by the encapsulation of the bitumenized waste in pastes and mortars was evaluated [11].

The tests performed to evaluate the bitumen used in Angra 2 were: penetration, softening point, flash point, water content, thermogravimetry and biodegradation $[12,13,14,15]$. The tests to evaluate the cement pastes (cement and water) and mortars (cement, water and sand) that can be used in the process of encapsulation of bituminized radioactive waste, were organized using the $2^{3}$ factorial design, in duplicate. The variables were: Formulation: pastes (-) (cement and water) and mortar (+) (cement, water and sand), absence (-) or presence $(+)$ of bentonite and with $(+)$ or without (-) chemical additive (plasticizer).

The tests performed on pastes and mortars were: viscosity, setting time, compressive strength at 28 days at age and density. To evaluate the bituminized product in pastes or mortars, the leaching test was carried out [16].

The experiment was chosen to have the most cost benefit and had the proper amount of bentonite, which will be important if there is contact with water to prevent the release of radionuclides. In this study, cement and mortar pastes were evaluated and to selected the ideal mixture for the encapsulation of the bituminized waste, based on the results of the leaching test.

\subsection{Preparation of the samples of bitumen encapsulated in cement pastes or mortars}

Based on the experiences of Romania and the Czech Republic, two options were selected for conditioning the bituminized waste, encapsulating it in cement paste or in mortar. A factorial design 
for the experiments was used the following factors: formulation, encapsulation diameter and amount of cesium chloride per sample as shown in Table 1 [6].

Table 1: Planning the experiments

\begin{tabular}{cccc}
\hline & & \multicolumn{3}{c}{ Variable } \\
\cline { 2 - 4 } Test & Formulation & Diameter & Diameter \\
\hline $\mathbf{1}$ & - & + & - \\
$\mathbf{3}$ & - & - & + \\
$\mathbf{4}$ & + & + & - \\
\end{tabular}

Formulation: cement paste (-); mortar (+)

Encapsulation diameter: $5 \mathrm{~cm} \mathrm{(-);5,8} \mathrm{cm} \mathrm{(+)}$

Amount of cesium chloride: $30 \mathrm{mg} \mathrm{(-);} 60 \mathrm{mg}(+)$

In Romania, $60 \mathrm{~L}$ drums are immobilized in cement within $200 \mathrm{~L}$ drums, that is, their volume is increased by 3.3 times. In the Czech Republic, $100 \mathrm{~L}$ drums are immobilized in concrete in $200 \mathrm{~L}$ drums, their volume being duplicated (Figure 3) [6].

Figure 3: Encapsulation of drums containing bituminized radioactive waste.
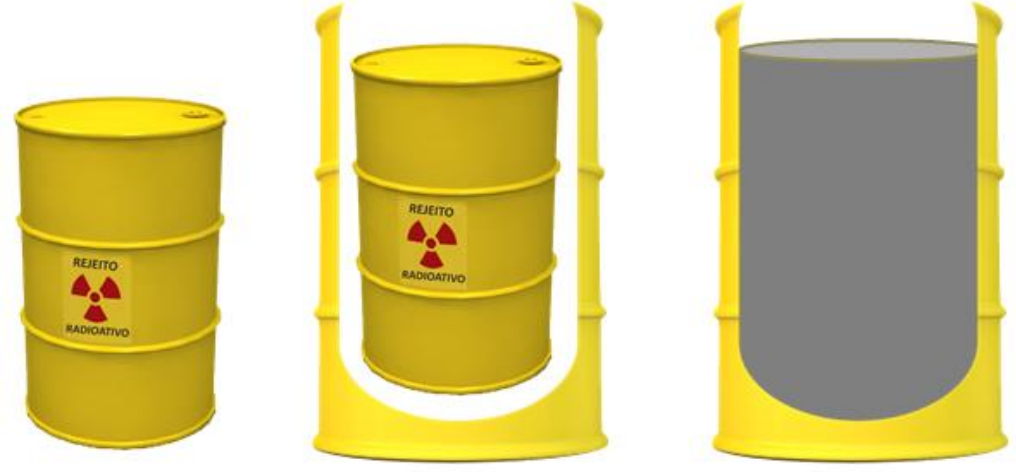

Source: Vieira, 2017.

To simulate the conditioning options, bitumen samples were prepared with $4 \mathrm{~cm}$ in diameter and $4 \mathrm{~cm}$ high (50.27 $\mathrm{cm}^{3}$ volume), which were encapsulated in cement paste and mortar with the following dimensions: $5 \mathrm{~cm}$ in diameter with $5 \mathrm{~cm}$ in height, obtaining a volume of $98.17 \mathrm{~cm}^{3}$ (volume 
increase of 1.95 times) and $5.8 \mathrm{~cm}$ in diameter with $5.8 \mathrm{~cm}$ in height, resulting in a volume 153.2 $\mathrm{cm}^{3}$ (volume three times greater than the initial) (Figure 4).

Different amounts of inactive cesium chloride were added to the bitumen sample $(30 \mathrm{mg}$ and 60 $\mathrm{mg}$ ) to verify the degree of retention of cesium chloride when in contact with water. The determination of the leachate exchange rates and their quantities were based on ISO 6961 [17].

Figure 4: The sample of bitumen (left) and bitumen encapsulation it in cement paste or in

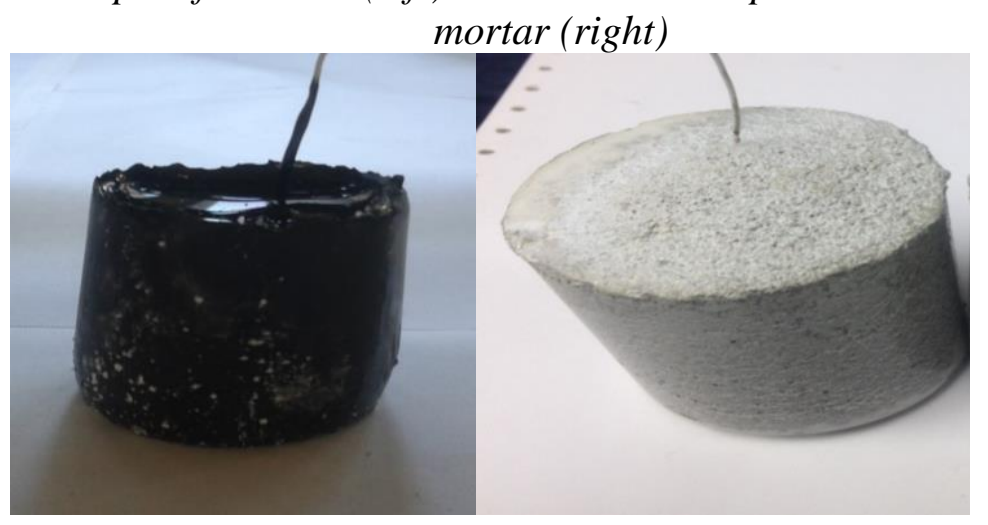

Source: Vieira, 2017.

\subsection{Determination of Leaching}

For the leaching test, the encapsulated samples were placed in 1,200 $\mathrm{mL}$ of deionized water. The leachate exchanges were performed every day in the first week; twice a week, for the second week; once a week in the third to sixth week, followed by monthly exchanges, over a period of one year, in duplicates. The samples of the leachate were sent for determination of the amount of cesium by atomic absorption. The results were expressed for each constituent by the leaching rate (TDL) of the increment $(\mathrm{Rn})$ as a function of time (t), as shown in equation (1). The TDL becomes constant after a certain time of renewal of the leachate, which will be indicated in the graph $\mathrm{Rn}$ versus $\mathrm{t}$.

$$
R_{n}=\frac{a_{n}}{A_{0} \times \mathrm{F} \times t_{n}}(1)
$$

$\mathrm{Rn}=$ incremental leaching rate $(\mathrm{TDL})\left(\mathrm{kg} / \mathrm{m}^{2} . \mathrm{s}\right)$,

an $=$ mass of the constituent leached at each interval $\mathrm{n}(\mathrm{kg})$,

$\mathrm{A}_{0}=$ fraction by weight of the constituent at the beginning of the test,

$\mathrm{F}=$ exposed surface area of the specimen $\left(\mathrm{m}^{2}\right)$,

$\mathrm{tn}=$ duration of the $\mathrm{nth}$ leaching interval $(\mathrm{s})$,

$\mathrm{n}=$ time increment. 


\section{RESULTS AND DISCUSSION}

From these results the leaching rates (TDL) of the same composition were calculated, the results in duplicates show similar values, demonstrating the reproducibility of the results. Table 3 shows the TDL averages of each experiment and the results are presented in Figure 5.

Table 3: TDL calculation averages

\begin{tabular}{ccccc}
\hline Time (Days) & $\begin{array}{c}\text { Experiment } \mathbf{1} \\
\text { TDL }\left(\mathbf{k g} / \mathbf{m}^{2} . \mathbf{s}\right)\end{array}$ & $\begin{array}{c}\text { Experiment } 2 \\
\text { TDL }\left(\mathbf{k g} / \mathbf{m}^{2} . \mathbf{s}\right)\end{array}$ & $\begin{array}{c}\text { Experiment } 3 \\
\text { TDL }\left(\mathbf{k g} / \mathbf{m}^{2} . \mathbf{s}\right)\end{array}$ & $\begin{array}{c}\text { Experiment } \mathbf{4} \\
\text { TDL }\left(\mathbf{k g} / \mathbf{m}^{2} . \mathbf{s}\right)\end{array}$ \\
\hline 1 & $2.65 \mathrm{E}-06$ & $1.65 \mathrm{E}-06$ & $6.66 \mathrm{E}-06$ & $5.53 \mathrm{E}-06$ \\
2 & $2.65 \mathrm{E}-06$ & $1.65 \mathrm{E}-06$ & $3.00 \mathrm{E}-06$ & $2.89 \mathrm{E}-06$ \\
3 & $2.65 \mathrm{E}-06$ & $1.65 \mathrm{E}-06$ & $2.59 \mathrm{E}-06$ & $2.15 \mathrm{E}-06$ \\
4 & $2.65 \mathrm{E}-06$ & $1.65 \mathrm{E}-06$ & $2.56 \mathrm{E}-06$ & $1.67 \mathrm{E}-06$ \\
7 & $8.85 \mathrm{E}-07$ & $5.49 \mathrm{E}-07$ & $1.79 \mathrm{E}-06$ & $1.39 \mathrm{E}-06$ \\
10 & $8.85 \mathrm{E}-07$ & $5.49 \mathrm{E}-07$ & $1.38 \mathrm{E}-06$ & $1.11 \mathrm{E}-06$ \\
16 & $4.42 \mathrm{E}-07$ & $2.75 \mathrm{E}-07$ & $8.54 \mathrm{E}-07$ & $6.43 \mathrm{E}-07$ \\
23 & $3.79 \mathrm{E}-07$ & $2.35 \mathrm{E}-07$ & $6.34 \mathrm{E}-07$ & $5.00 \mathrm{E}-07$ \\
30 & $3.79 \mathrm{E}-07$ & $2.35 \mathrm{E}-07$ & $6.01 \mathrm{E}-07$ & $4.51 \mathrm{E}-07$ \\
37 & $3.79 \mathrm{E}-07$ & $2.35 \mathrm{E}-07$ & $4.72 \mathrm{E}-07$ & $3.34 \mathrm{E}-07$ \\
67 & $8.85 \mathrm{E}-08$ & $5.49 \mathrm{E}-08$ & $2.88 \mathrm{E}-07$ & $9.82 \mathrm{E}-08$ \\
98 & $8.56 \mathrm{E}-08$ & $5.32 \mathrm{E}-08$ & $1.22 \mathrm{E}-07$ & $7.12 \mathrm{E}-08$ \\
128 & $8.85 \mathrm{E}-08$ & $5.49 \mathrm{E}-08$ & $9.61 \mathrm{E}-08$ & $7.37 \mathrm{E}-08$ \\
159 & $8.56 \mathrm{E}-08$ & $5.32 \mathrm{E}-08$ & $8.76 \mathrm{E}-08$ & $5.39 \mathrm{E}-08$ \\
190 & $8.56 \mathrm{E}-08$ & $5.32 \mathrm{E}-08$ & $8.40 \mathrm{E}-08$ & $5.39 \mathrm{E}-08$ \\
218 & $8.85 \mathrm{E}-08$ & $5.49 \mathrm{E}-08$ & $8.55 \mathrm{E}-08$ & $5.57 \mathrm{E}-08$ \\
249 & $9.15 \mathrm{E}-08$ & $5.68 \mathrm{E}-08$ & $8.54 \mathrm{E}-08$ & $5.77 \mathrm{E}-08$ \\
279 & $8.85 \mathrm{E}-08$ & $5.49 \mathrm{E}-08$ & $8.27 \mathrm{E}-08$ & $5.39 \mathrm{E}-08$ \\
310 & $8.56 \mathrm{E}-08$ & $5.32 \mathrm{E}-08$ & $8.54 \mathrm{E}-08$ & $5.26 \mathrm{E}-08$ \\
340 & $8.85 \mathrm{E}-08$ & $5.49 \mathrm{E}-08$ & $8.40 \mathrm{E}-08$ & $5.09 \mathrm{E}-08$ \\
371 & $8.56 \mathrm{E}-08$ & $5.46 \mathrm{E}-08$ & $8.40 \mathrm{E}-08$ & $5.09 \mathrm{E}-08$ \\
\hline
\end{tabular}

It is observed that each exchange showed a peak in the graph due to the accumulation of cesium leached during the exchange periods (Figure 5) until the release of cesium at constant rate.

The graphs exhibit similar behavior in which there is a considerable decrease in the rate of cesium leachate. The first changes showed higher leaching rates due to the leaching of a large part of the cesium present on the sample surfaces and easy to remove. With the continuity of the ex- 
change process, this rate decreases due to the difficulty of removing cesium chemically bonded to the cement, which is found in the inner layers of the specimen.

Analyzing the leaching tests between the two groups of experiments (pastes, 1 and 2; mortar, 3 and 4) it is seen that the cesium leach rate from the pastes samples was lower than those released by mortar. This may be due to the presence of sand in the composition, which increases the number of pores in the sample, which results in greater ease of release of cesium.

According to PEREIRA and TELLO the results of pastes and mortars for the encapsulament of bituminized radioactive waste the leaching test (TDL) of the pastes presented values between 5.68E-06 in the first exchanges and 1.62E-07 in the last exchanges. The mortars presented higher values between 1.53E-05 and 1.67E-07 [18].

Figure 5: Leaching rate in relation to leaching time

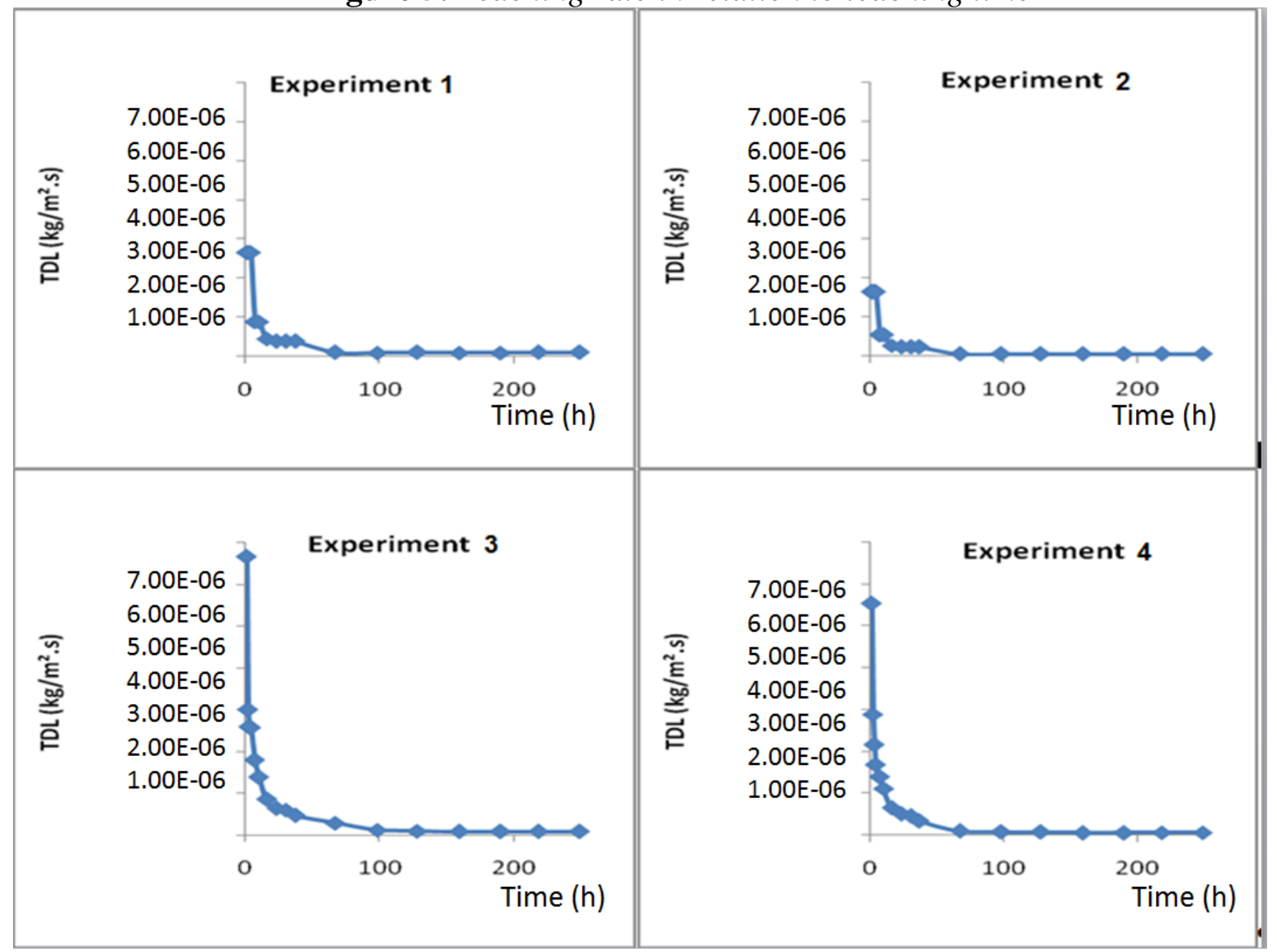


Source: Vieira, 2017.

\section{CONCLUSION}

This study presented possible solutions for the deposition bituminized waste in a near-surface repository, making it compatible with the facility's waste acceptance criteria. For this purpose the encapsulation of bitumen in paste or mortar was carried out and evaluated the properties of bitumen, paste, mortar and encapsulated bitumen.

The results obtained in the leaching test (samples A and B) present similar results, verifying the reproducibility of the results. Experiments using paste presented better results compared to mortar, since these compositions were able to retain a greater amount of cesium in the sample.

Applied to the context of the repository, its use would be more satisfactory, since it would act to retain part of the radionuclides present in the radioactive waste and would increase the safety in the repositories of bituminized radioactive waste, delaying or decreasing the release of radionuclides released into nature. Therefore, the proposal to encapsulate cement bitumen product allows its acceptance for the deposition of these wastes in the near-surface repository.

\section{ACKNOWLEDGMENT}

This work was performed at the Laboratory of Cementation CDTN - LABCIM. The tests were performed with the help from Maria Judite Afonso Haucz, Francisco Donizete Cândido, Sandro Seles, Adair Generoso do Carno and Marina Gregório.

This research project is supported by the following Brazilian institutions: Nuclear Technology Development Center (CDTN), Brazilian Nuclear Energy Commission (CNEN), Research Support Foundation from the State of Minas Gerais (FAPEMIG), and The Brazilian Council for Scientific and Technological Development (CNPq).

\section{REFERENCES}

1. ELETRONUCLEAR. Eletronuclear: Panorama da energia nuclear no mundo. Available at: < http://www.eletronuclear.gov.br > Last accessed: 10 Sept. 2017. 
2. TELLO, C. C. O. Projeto de repositório para rejeitos radioativos de baixo e médio níveis de radiação. Relatório Técnico - Centro de Desenvolvimento da Tecnologia Nuclear Belo Horizonte: CDTN / CNEN, Brasil, 2008.

3. MCT - Ministério da Ciência e Tecnologia. Ciência, Tecnologia e Inovação para o Desenvolvimento Nacional. Plano de Ação, MCTIE, Brasília, Brazil, 2007.

4. BRASIL - Lei $\mathbf{n}^{\mathbf{0}}$ 10.3085. Seleção de locais, a construção, o licenciamento, a operação, a fiscalização, os custos, a indenização, a responsabilidade civil e as garantias referentes aos depósitos de rejeitos radioativos, e dá providências. DOU, Brasília, Brazil, 2001.

5. TELLO, C.C.O. Efetividade das bentonitas na retenção de césio em produtos de rejeitos cimentados, UNICAMP, Campinas, Brazil, 2001.

6. C.C.O. Tello; V. Cuccia, Experiência Internacional no uso da betuminização como processo de solidificação de rejeitos radioativos, Centro de Desenvolvimento da Tecnologia Nuclear, Belo Horizonte, Brazil, 2011.

7. VALCKE, R.Gens, The Belgian approach towards the study of the compatibility of Eurobitum with the geological disposal enviromente. Belgian Nulear Research Centre Mol: SCK•CEN, Belgian, 2007.

8. BURAKOV, B., ALOY, E. A. S. The methodology followed in Belgium to investigate the compatibility with geological disposal of Eurobitum bituminized intermediate-level radioactive waste. Scientific basis for nuclear waste management XXXIII. Symposium. St. Petersburg, Rússia, 2009.

9. IAEA - International Atomic Energy Agency. Selection of technical solutions for the management of radioactive waste. Vienna, 2017 (Technical report series, 1817).

10. MOKNI, S. Oliveira, VALCKIE, E, MARIEN, A, SMETS, S. Creep and swelling of a bituminized radioactive waste. Interaction with the clay host formation. Waste confinement 4 th international meeting. Nantes, France, 2010.

11. CNEN-NN-6.09 - Comissão Nacional de Energia Nuclear. Critérios de aceitação para deposição de rejeitos radioativos de baixo e médio nível de radiação. Rio de Janeiro, Brazil, 2002.

12. ABNT - Associação Brasileira de Normas técnicas. NBR 6.576. Determinação da penetração de materiais betuminosos. Rio de Janeiro, Brasil, 1998. 
13. ABNT - Associação Brasileira de Normas Técnicas. NBR 11.341. Determinação dos pontos de fulgor e de combustão em vaso aberto Cleveland. Rio de Janeiro, Brazil, 2000a.

14. ABNT - Associação Brasileira de Normas Técnicas. NBR 6.560. Determinação do ponto de amolecimento de materiais betuminosos. Rio de Janeiro, Brasil, 2000b.

15. ABNT - Associação Brasileira de Normas Técnicas. NBR 14.236. Produtos de petróleo e materiais betuminosos. Determinação do teor de água por destilação. Rio de Janeiro, Brasil, 2002.

16. ABCP - Associação Brasileira do Cimento Portland. Manual de ensaios físicos de cimento. São Paulo: ABCP, Brasil, 1994.

17. ISO - International Organization for Standardization. ISO 6961: Long-term leach testing of solidified radioactive waste forms. Geneva: ISO, 1982.

18. TELlO, C. C. PEREIRA, A. C. S. Avaliação de pastas e argamassas para o embalado de rejeitos betuminizados. International Nuclear Atlantic Conference - INAC. São Paulo, Brasil, 2015.

19. VIEIRA, V. M. Estudo de Encapsulamento de Rejeitos Radioativos Betuminizados para Armazenamento em Repositório de Superfície. Centro de Desenvolvimento da Tecnologia Nuclear - Belo Horizonte: CDTN / CNEN, 2017.

20. IAEA - INTERNATIONAL ATOMIC ENERGY AGENCY. Selection of technical solutions for the management of radioactive waste (Technical report series, 1817). Vienna, 2017.

21. BURAKOV, B., ALOY, E. A. S. The methodology followed in Belgium to investigate the compatibility with geological disposal of Eurobitum bituminized intermediate-level radioactive waste. Scientific basis for nuclear waste management XXXIII. Symposium. St. Petersburg, Rússia, 2009.

22. MOKNI, S. Oliveira, VALCKIE, E, MARIEN, A, SMETS, S. Creep and swelling of a bituminized radioactive waste. Interaction with the clay host formation. Waste confinement 4 th international meeting. Nantes, France, 2010.

23. AMERICAN SOCIETY TESTING AND MATERIALS. ASTM C1308: standard test method for accelerated leach test for diffusive releases from solidified waste and a computer program to model diffusive, fractional leaching from cylindrical waste forms. Pennsylvania, USA, 2017. 